\title{
Influential variables on the profitability of hospital companies
}

\author{
Judit Creixans-Tenas (D), Núria Arimany-Serrat (D) \\ Universitat de Vic - UCC (Spain) \\ judit.creixans@uvic.cat,nuria.arimany@uvic.cat
}

Received July, 2017

Accepted October, 2017

\begin{abstract}
Purpose: This study attempts to evidence the economic and financial health of Spanish hospital companies in the period 2008-2015 and discover the variables that explain their profitability for survival and the opportune performance of their assets during a period of technological revolution and austerity.

Design/methodology: The study methodology consists of the short and long-term financial analysis of the companies in the study sample during the period 2008-2015, together with analysis is of their economic state, equity and treasury. To add value to the research, the profitability of the hospital companies has been explained in terms of the following independent variables: short-term solvency, debt, business size, legal form, GDP per capita, population density of and indicators of Corporate Social Responsibility.
\end{abstract}

Findings: In the analyzed period, the economic and financial health of hospital companies is characterized by acceptable liquidity and indebtedness that significantly influence its profitability; this is accompanied by good financial and expenditure management, though it is necessary to improve the management of assets.

Research limitations/implications: It was not possible to obtain data for 2016, as it was not available in the database used (SABI). These data would have been useful to evaluate the changes in trends that are taking place in the health sector due to the technological revolution and economic policies affecting it.

Practical implications: The health sector is one of the pillars on which society is based, and therefore knowing detailed economic and financial information allows us to make appropriate decisions, both on the hospital level and in terms of the economic policies of governments.

Social implications: This study provides evidence of the financially relevant indicators that healthcare companies must control for their survival and to provide proper service to society in general. The research also identifies non-financial variables that contribute to improving the profitability of hospital companies, while also having a good impact on society.

Originality/value: To indicate financial and non-financial measures to improve the profitability of hospital companies at a time of technological innovation and austerity.

Keywords: Economic and financial analysis, Hospital companies, Profitability, Healthcare industry, Liquidity, Indebtedness 


\section{Introduction}

In the context of the economic crisis of recent years, the economic and financial situation of the Spanish healthcare industry is a concern of direct managers in both the public and the private sphere. In fact, the austerity of the last decade has led to a decline in public spending aimed at meeting the needs of the healthcare and educational systems, resulting in shortcomings in the operation of two of the fundamental pillars of any society. In addition, in recent years, the demand for care has increased considerably, and continues to grow year after year as the population increases, as a consequence of the aging Spanish population. This fact causes the public health system to seek collaborative synergies with the private healthcare system, in order to achieve an efficient functioning in terms of the demand for healthcare, waiting lists and financial pressure.

According to the data and information provided by the Report on the Situation of Private Health (Instituto para el Desarrollo e Integración de la Sanidad, 2017), which is developed on an annual basis by the IDIS Foundation, it is evident that the private health sector contributes in a significant manner to the development of the healthcare system, since it frees up the public system and promotes its savings, thus constituting a key strategic collaborator for the sustainability, accessibility and quality of health care for citizens. The same report estimates that a person who exclusively uses the private health system saves the National Health System 1,134 euros per year. Therefore, given that Spain has about 7.8 million people with private insurance, it is corroborated that the duality of private health and public health contributes to maintaining the level of care, shorter waiting lists and savings in the public system.

In 2014, Spanish healthcare expenditure stood at $9.1 \%$ of the GDP, representing a slight increase over the figure for the previous year. This is due to the increase in private health expenditure as compared to the total health expenditure, since public expenditure has shown a decreasing trend over these years. On the other hand, the weight of private health expenditure as compared to the total health expenditure (30.2\%) places Spain above the average for the OECD countries.

For the sake of analysis, it must be kept in mind that the private health sector currently has a total of 452 hospitals in Spain, which represent $57 \%$ of the total hospital centers in the country. The Autonomous Communities of Catalonia, Madrid and Andalusia are the ones that are the most privatized, with the greatest number of hospitals and private hospital beds. It should be noted that $58 \%$ of this private hospital sector is made up by hospital groups, 39\% by independent hospitals and 3\% by insurance companies.

The work presented here analyzes the economic and financial health of the companies that carry out hospital activities in the private healthcare system, in order to assess whether good management and administrative practices are being followed. It must be kept in mind that in the current economic environment, business profitability is one of the aspects of greatest interest for companies (Cortés, Rayo \& Lara, 2011) and in the case of hospital companies belonging to the private healthcare system, it is necessary in order to identify the main explanatory factors behind this profitability (economic, financial or other).

In the study carried out following the literature review, significant relationships between economic profitability and financial indicators of the analysis of financial statements are identified, along with other indicators (business size, legal form, GDP, population density and indicators of Corporate Social Responsibility (CSR)), and the characterization of measurement instruments and variables. Subsequently, the empirical study of the sample in the 2008-2015 period is specified to permit the discussion of the results and the drawing conclusions.

\section{Review of the literature}

The analysis of the financial statements integrates a set of techniques to diagnose the situation and give a perspective on the status of the company in economic and financial terms, in order to be able to make the most 
appropriate decisions. This analysis must be complemented with the study of other factors, such as the legal structure, the market situation, and the quality and productivity of companies (Amat, 2000).

The financial indicators of the hospital centers show the relationship between items on the financial statements in the form of ratios to determine the financial and economic position of companies (Lee \& Choi, 2011).

In the research by Pink, Daniel, McGillis and McKillop (2007), the authors defined the best financial indicators in the hospital sector. Specifically, they determined that to predict whether hospitals have a good financial situation, we must analyze the financial profitability, economic profitability, liquidity, short-term solvency, working capital, cash flow, capitalization, debt and the quality of this debt. Cleverley (1990) did a study of all hospitals in the United States and concluded that profitability, capital structure and liquidity are the indicators that need to be analyzed for any company of this type.

It should be noted that there are hardly any analytical studies of the financial statements of Spanish hospital companies. The study by Giner, Lorenzo and Abásolo (2005), which analyzes the economic and financial situation of the private hospitals in the Canary Islands and the subsequent study of private hospitals in Catalonia (Creixans-Tenas \& Arimany-Serrat, 2016), is worthy of note.

Currently, taking into account the effect of the economic crisis on the health field, the drop in economic activity and the financial restrictions on access to credit, the profitability ratios of these companies have worsened, with negative effects on the company's occupation In this context, analyzing business profitability is more relevant, along with the analysis of the main explanatory factors of this profitability with the objective of producing tools or models that explain the profitability and that can improve long-term financial planning (Cortés et al., 2011).

A review of the business literature reveals that there are two theories providing alternative explanations regarding the factors that affect the profitability of a company. On the one hand, the first theory supposes that the profitability of the company depends on the structural characteristics of the industry or the sector in which it operates (Scherer \& Ross, 1990). On the other hand, the second theory supposes that profitability is determined by the capabilities and equity of each company (Barney, 1991; Peteraf, 1993).

Ona theoretical level, the DuPont model (González-Pascual, 2016) establishes the relationships between financial and economic profitability and a set of accounting variables and ratios, such as asset turnover, sales margin andleverage. However, other authors (Choi \& Lee, 2008; Coyne, 1982) reaffirm that the indicator of economic profitability in hospitals is the most relevant and is considered the best standard to measure the economic and financial situation.

For this reason, economic profitability will be used as a dependent variable in this study, and both internal variables (financial indicators) and external (location and business sector) will be used as explanatory variables. Lee (2015) points out that private hospital companies must achieve profits and good returns in order to be efficient, so they must study the factors that influence and explain these returns. In a similar manner, other authors (Turner, Broom, Elliott \& Lee, 2015) indicate that a long-term financial vision of hospital companies is needed, in order to achieve the goals of generating positive financial and economic returns.

Various authors (Bem, Predkiewicz, Predkiewicz \& Ucieklak-Jez, 2014; Bem, Predkiewicz, Ucieklak-Jez \& Siedlecki, 2015; Benton, 2013; Coyne, 1982; Gapenski, Vogel \& Langland-Orban, 1993) have found that explanatory variables of profitability are varied, but those that have the greatest influence are indebtedness and solvency (as internal variables) and market evolution, business size and geographical area (as external variables). Regarding external variables, Amat (2000) states that the evolution of external aspects conditions the development of any company, and there is a high correlation between the economy (defined in terms of Gross Domestic Product (GDP)) and the trend of company results (profitability). In addition, the business size and geographical area must be taken into account (a hospital located on an industrial belt is not the same as one located a long distance away from urban centers). In this sense, Eldenburg and Krishnan (2003) and Palomo and Mateu (1999) link the macroeconomic variables of dimension and results to the macroeconomic variables that configure their respective environments of activity (with explanatory variables understood to be the density of 
the population and GDP per capita). Luna, Restrepo and Zúñiga (2009) explain that SMEs have economic returns that correlate positively to changes in GDP, and authors such as Mick and Wise (1996) point out that profitability is higher in larger hospitals, while hospitals located in densely populated areas with a higher GDP have better results.

Regarding the relationship between the business size and profitability, although there are authors who disagree (Ayala \& Navarrete, 2004), many studies (Ayala \& Navarrete, 2004; French III, 1996; Ocaña, Salas \& Vallés, 1994; Robinson \& Phibbs, 1990; Sánchez \& Bernabé, 2002) reveal the existence of a significant relationship between these two variables. Other authors (Turner et al., 2015) also explain the profitability through legal form of the hospital, with a significant relationship.

Regarding the internal variables, variables that are directly linked to economic profitability are debt, solvency and productivity (Bem et al., 2014, 2015; Vélez-González, Pradhan \& Weech-Maldonado, 2011). Specifically, the lowest-performing hospital centers are the ones that are most indebted.

Watkins (2000) notes that financial studies of hospitals analyze the financial information from accounting statements, but other authors claim that non-financial information, together with financial ratios, provide more added value to diagnose the health of hospital companies (Cleverley, 1990). Furthermore, in recent years, there has been a significant growth in the interest by the population inthe transparency of entities in terms of sustainability (Nevado-Gil \& Gallardo-Vázquez, 2016). The number of organizations that report on issues related to economic, social and environmental behavior have increased (Frías-Aceituno, Marques \& RodríguezAriza, 2013; Marín-Calahorro, 2008; Prado-Lorenzo \& García-Sánchez, 2010). Thus, more and more hospitals adopt Corporate Social Responsibility (CSR) criteria and use their corporate websites to disseminate best practices and sustainability reports (Rodríguez-Cala, Calle-Rodríguez, Durán-Garcia \& Zöller, 2015). CSR indicators are found in sustainability reports or environmental and quality accreditations, among others (Satorras, 2002). In addition, different studies have related profitability to CSR (Miras-Rodríguez, Carrasco \& Escobar, 2011; Navarro \& González, 2006; Vélez-González et al., 2011). Some authors claim that when a company has or is reported to have a sustainability report, it tends to have a better economic and financial situation (Antunes \& Gallardo, 2016). Other authors point out that financial indicators improve when credibility reports are credited, but there are no unified criteria relating CSR and profitability (Setó \& Angla, 2011).

Bearing in mind this literature, and with the main objective of determining the economic and financial health of Spanish hospital companies and the explanatory variables that influence the economic profitability of these companies, the following hypotheses are proposed for Spanish hospital companies:

H1: There is a significant relationship between short-term solvency and economic profitability.

H2: There is a significant relationship between indebtedness and economic profitability.

H3: There is a significant relationship between the business size and the economic profitability.

H4: There is a significant relationship between legal form and economic profitability.

H5: There is a significant relationship between GDP per capita and economic profitability.

H6: There is a significant relationship between population density and economic profitability.

H7: There is a significant relationship between the presence of CSR indicators and economic profitability.

\section{Defining and measuring variables}

For the economic and financial analysis of Spanish hospital companies, the financial indicators used were: working capital, short-term solvency, debt, debt quality, financial profitability, economic profitability, asset turnover, leverage and staff productivity. On the other hand, to explain the variables that affect the economic profitability (dependent variable of the study) of these companies, in accordance with the previous literature, 
short-term solvency, debt, business size, legal form, GDP per capita, population density and indicators of Corporate Social Responsibility (CSR) were considered.

\subsection{Dependent variable}

The dependent variable is the return on assets (ROA), i.e., the profitability of the assets of each of the companies analyzed, which has been calculated by correlating the profit before taxes and interests (BAIT) and the total assets of each of these hospital companies.

\subsection{Independent variables}

The independent or explanatory variables of the return on assets or economic profitability were:

- Short-term solvency (quotient of current assets and current liabilities).

- Indebtedness (debt ratio with respect to total net worth and liabilities).

- Business size (Napierian logarithm of the total assets (Mejía, 2015)).

- Legal form(qualitative variable, considered 0 if it is a private limited company, and 1 if it is a public limited company).

- GDP per capita (data from the National Institute of Statistics (INE, 2015)).

- Population density (calculated as the quotient between the number of inhabitants and the square kilometers at the location of the company's registered office).

- CSR indicators (qualitative variable, value is 1 if the hospital company has sustainability reports according to the Global Reporting Initiative (GRI) (2015), ISO accreditations (9.001, 14.001, 26.000, $50.001)$ or quality accreditations (EFQM or JCI) on their website (Satorras, 2002) and value 0 otherwise).

\section{Research methodology}

The methodology involved a financial economic analysis of these Spanish hospital companies duringthe period 2008-2015, using the accounting and financial information from the SABI database and information presented in the Companies Registry for these companies. The sample obtained corresponds to the following search items:

- Period 2008-2015

- Active companies

- Hospital activity (CNAE 2009: 8610)

- Legal form(private limited companies and public limited companies)

- Large and medium-sized businesses (net amount of business and assets exceeding 8 and 4 million euros, respectively, and with more than 50 employees, according to European Directive 2013/34/EU)

- Companies with full annual accounts for the last year.

Keep in mind that the European Directive 2013/34/EU identifies a large company as one with a net turnover exceeding 40 million euros, assets exceeding 20 million euros and with more than 250 employees; a medium company has a net turnover figure of between 8 and 40 million euros and assets of between 4 and 20 million euros and has between 50 and 250 workers.

The sample obtained is made up of 80 hospital companies, which in terms of turnover, represent $75 \%$ of the total number of Spanish hospital companies. 
In order to give added value to the research, the return on assets or economic profitability has been related to the following explanatory variables for 2015: short-term solvency, indebtedness, business size, legal form, GDP per capita, population density and Corporate Social Responsibility indicators CSR). It has been proven that there was no outlier distorting the results obtained, and the hypotheses set out above have been contrasted by means of inferential statistics.

Short-term solvency variables, indebtedness and business size have been calculated from the financial statements for the 2015 financial year for the 80 companies in the sample. Legal form has been obtained from the SABI database, and GDP variables per capita and population density are determined by data from the National Institute of Statistics. With respect to the CSR indicators, the websites of the companies in the sample have been consulted.

To correlate return on assets with the rest of the variables, statistical methods have been applied (using the IBM SPSS Statistics 22 statistical program), including Kolmogorov-Smirnov normality tests; tests of homogeneity as determined by the Levene statistic; Student's t-test for independent samples and correlation tests using Pearson's correlation coefficient (Bem et al., 2014, 2015).

\section{Characterization of the study sample}

Companies that perform hospital activities in the sample are distributed mostly throughout Madrid, Catalonia and Andalusia, the autonomous communities with the most privatized health care and the most hospital care companies, according to the IDIS report (Instituto para el Desarrollo e Integración de la Sanidad, 2017) (Figure 1).

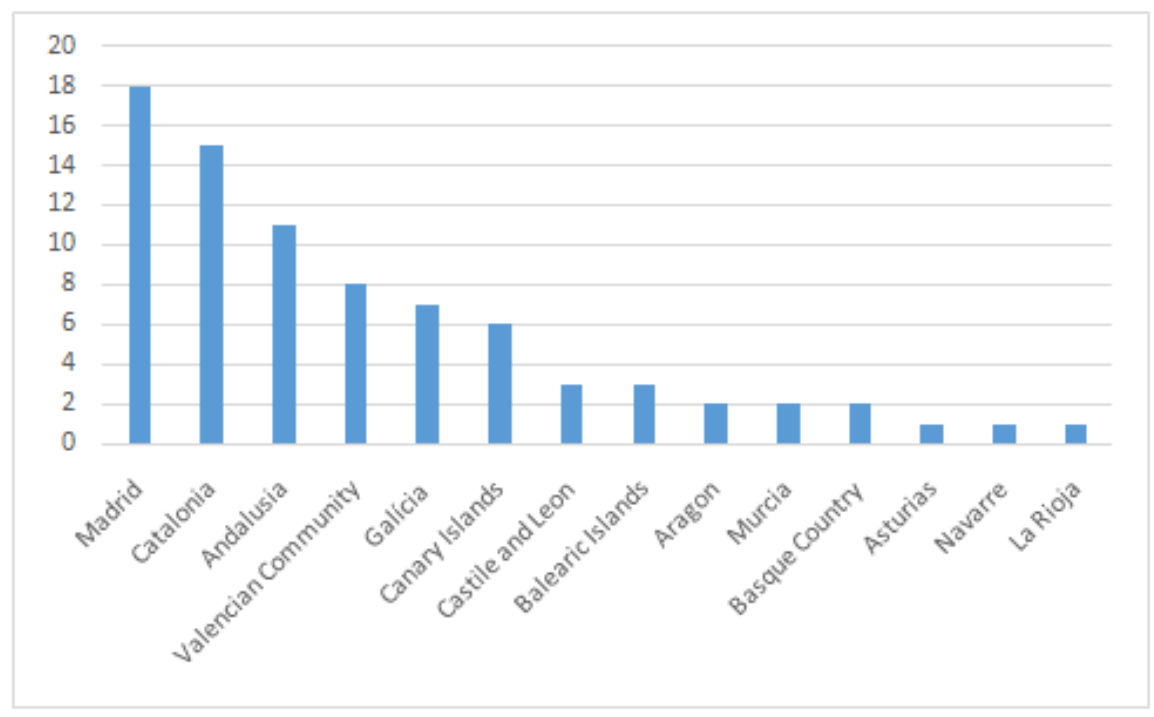

Figure 1. Geographical distribution of Spanish hospital companies

Regarding legal form, most companies are public limited companies (Figure 2).

The number of employees of these companies has increased during this period, to an average of 477 workers(Figure 3).

About $64 \%$ of these companies were established more than 20 years ago, and only 7 hospital companies were created during the period 2008-2015. Furthermore, according to European Directive 2013/34/EU, most of the companies in the sample are medium-sized (Figure 4). 


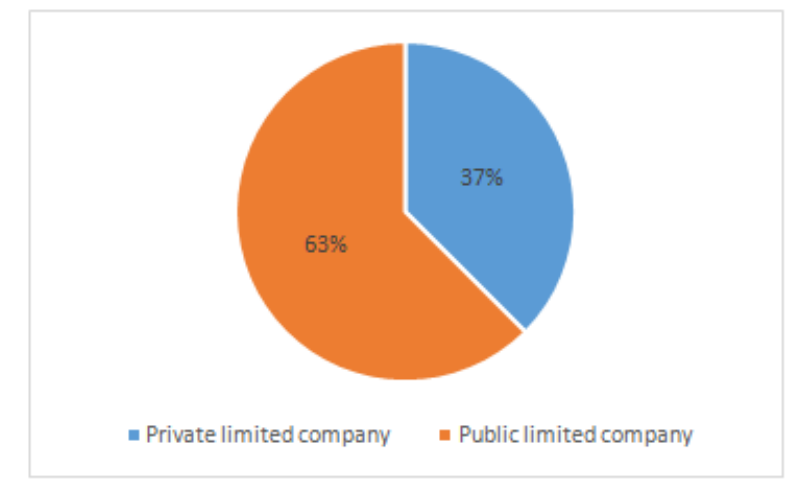

Figure 2. Legal form of Spanish hospital companies

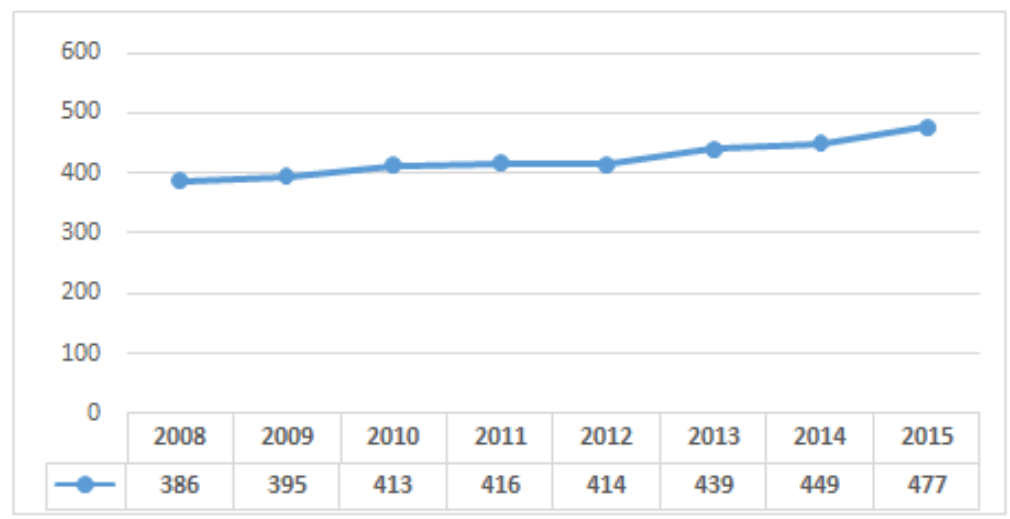

Figure 3. Evolution of the number of employees in Spanish hospital companies

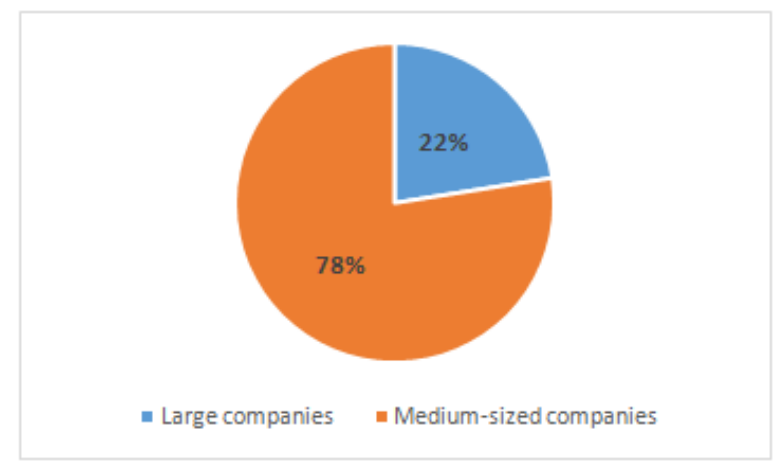

Figure 4. Size of Spanish hospital companies

\section{Results of the study}

\subsection{Economic and financial analysis}

The economic and financial situation during the period 2008-2015 as based on the opportune financial indicators of the hospital centers that make up the sample has been structured in different sections: general analysis of the financial and economic structure, analysis of the financial situation over the short and long term, economic analysis and analysis of assets and treasury funds. 


\subsubsection{Analysis of the financial assets and liabilities of the economic and financial structure}

The evolution of the net worth over these eight years shows an upward trend, as both the assets and net worth have increased (the companies have capitalized 60\%). On the other hand, there is a balance between the economic and financial structure of the average financial assets and liabilities (Figure 5).

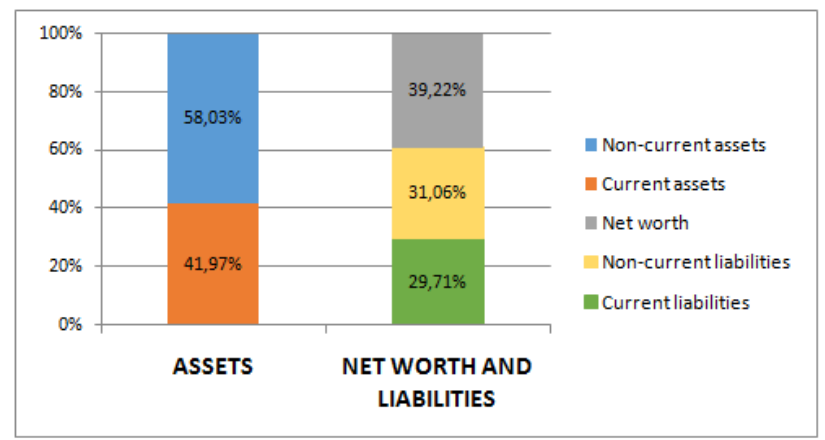

Figure 5. Structure of the financial assets and liabilities

\subsubsection{Analysis of the short-term financial situation}

The working capital is positive for all the fiscal years and increases considerably during the period analyzed. Short-term solvency reflects appropriate values during the period 2012-2015 (in the previous years, it is low due to the effects of the economic crisis) and the cash flows from the operating activity are positive in all the fiscal years of the study. Accordingly, these hospital companies can meet their short-term payment obligations (Table 1).

\begin{tabular}{|c|c|c|c|c|c|c|c|c|}
\hline & 2008 & 2009 & 2010 & 2011 & 2012 & 2013 & 2014 & 2015 \\
\hline Working capital (€'000) & 1,387 & 3,610 & 3,830 & 4,514 & 7,445 & 7,117 & 8,372 & 8,541 \\
\hline Short-term solvency & 1.13 & 1.30 & 1.31 & 1.33 & 1.55 & 1.48 & 1.54 & 1.52 \\
\hline $\begin{array}{l}\text { Cash flows from operating } \\
\text { activities }\left(€^{\prime} 000\right)\end{array}$ & $2,139.05$ & $3,114.50$ & $3,349.96$ & $1,956.99$ & $2,816.94$ & $4,017.95$ & $3,678.02$ & 4,9 \\
\hline
\end{tabular}

Table 1. Financial indicators of the short-term financial situation

\subsubsection{Analysis of the long-term financial situation}

The asset turnover is around 11 months, i.e. the value of the investments is recovered in that time. Regarding the debt ratio, the hospitals present moderate levels of indebtedness, with around $60 \%$ of good quality (the shortterm debts represent $50 \%$ ). Between $5 \%$ and $7 \%$ of the debts over the short term are with credit entities (Table 2).

\begin{tabular}{|l|r|r|r|r|r|r|r|r|}
\cline { 2 - 9 } \multicolumn{1}{c|}{} & \multicolumn{1}{c|}{$\mathbf{2 0 0 8}$} & \multicolumn{1}{c|}{$\mathbf{2 0 0 9}$} & \multicolumn{1}{c|}{$\mathbf{2 0 1 0}$} & $\mathbf{2 0 1 1}$ & $\mathbf{2 0 1 2}$ & $\mathbf{2 0 1 3}$ & $\mathbf{2 0 1 4}$ & \multicolumn{1}{c|}{$\mathbf{2 0 1 5}$} \\
\hline Debt ratio & $61.25 \%$ & $61.43 \%$ & $59.51 \%$ & $61.37 \%$ & $59.22 \%$ & $60.49 \%$ & $61.78 \%$ & $61.16 \%$ \\
\hline Debt quality ratio & $50.15 \%$ & $50.11 \%$ & $49.34 \%$ & $47.57 \%$ & $47.54 \%$ & $49.03 \%$ & $48.23 \%$ & $49.71 \%$ \\
\hline Asset turnover & 0.91 & 0.89 & 0.89 & 0.79 & 0.79 & 0.83 & 0.82 & 0.85 \\
\hline
\end{tabular}

Table 2. Financial indicators of the long-term financial situation

Moreover, according to the criterion used by Amat and Perramon (2011), there is evidence of prudent financial management during this period (since the increase in assets is higher than that of the debt). There has also been good management of expenses (since the results have increased more than sales), but there is no evidence of efficient asset management (since assets have grown more than sales) (Table 3). 


\begin{tabular}{|c|c|r|r|r|r|}
\hline \multicolumn{2}{|c|}{$\begin{array}{c}\text { Efficient asset } \\
\text { management }\end{array}$} & \multicolumn{2}{c|}{$\begin{array}{c}\text { Prudent financial } \\
\text { management }\end{array}$} & \multicolumn{2}{c|}{ Management of expenses } \\
\hline $\begin{array}{c}\Delta \\
\text { Turnover }\end{array}$ & $\boldsymbol{\Delta}$ Assets & $\boldsymbol{\Delta}$ Assets & $\boldsymbol{\Delta}$ Debts & $\boldsymbol{\Delta}$ Results & $\boldsymbol{\Delta}$ Turnover \\
\hline $49.168 \%$ & $59.873 \%$ & $59.873 \%$ & $59.636 \%$ & $166.677 \%$ & $49.168 \%$ \\
\hline
\end{tabular}

Table 3. Balanced growth indicators

However, it can be said that the Spanish hospital entities have a good financial situation over the long term, but they need to manage their assets better.

\subsubsection{Economic analysis}

The profitability analysis reflects that the return on equity (ROE) increases by $70 \%$ in the period considered, with a decrease in profits for the year in 2011 (due to the effects of the crisis) that has been recovering since 2013, despite the variations in this financial indicator. Return on assets (ROA) remains practically stable throughout the period analyzed, with a growth of $5 \%$.

Throughout the period, the ROE is above the ROA (Figure 6 and Table 4), with the exception of in 2008, and thus indebtedness does not place the analyzed hospital centers at risk (this is also corroborated by a higher financial leverage than the unit in all fiscal years, except for 2008 (Table 4)).

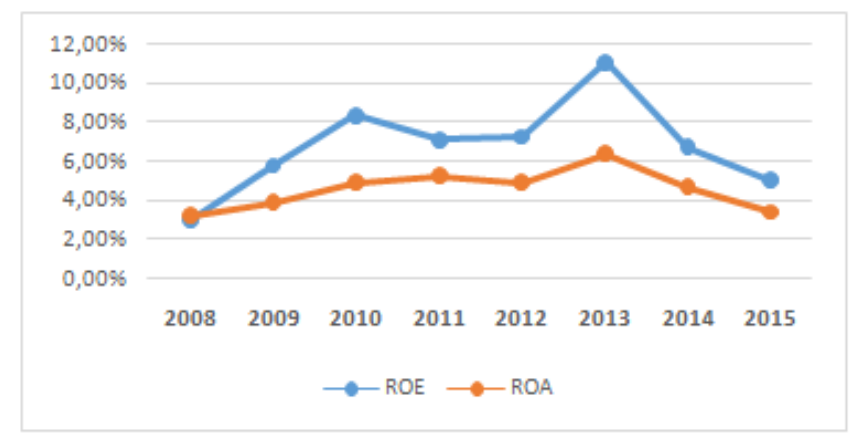

Figure 6. Evolution of return on equity (ROE) and return on assets (ROA)

\begin{tabular}{|l|r|r|r|r|r|r|r|r|}
\cline { 2 - 9 } \multicolumn{1}{c|}{} & \multicolumn{1}{c|}{$\mathbf{2 0 0 8}$} & \multicolumn{1}{c|}{$\mathbf{2 0 0 9}$} & \multicolumn{1}{c|}{$\mathbf{2 0 1 0}$} & \multicolumn{1}{c|}{$\mathbf{2 0 1 1}$} & \multicolumn{1}{c|}{$\mathbf{2 0 1 2}$} & \multicolumn{1}{c|}{$\mathbf{2 0 1 3}$} & \multicolumn{1}{c|}{$\mathbf{2 0 1 4}$} & $\mathbf{2 0 1 5}$ \\
\hline ROA & $3.25 \%$ & $3.93 \%$ & $4.92 \%$ & $5.29 \%$ & $4.97 \%$ & $6.41 \%$ & $4.73 \%$ & $3.43 \%$ \\
\hline ROE & $2.98 \%$ & $5.79 \%$ & $8.38 \%$ & $7.11 \%$ & $7.27 \%$ & $11.12 \%$ & $6.76 \%$ & $5.06 \%$ \\
\hline Leverage & 0.89 & 1.40 & 1.57 & 1.25 & 1.36 & 1.56 & 1.34 & 1.41 \\
\hline
\end{tabular}

Table 4. Analysis of profitability and financial leverage

Regarding the added value, the increase in operating income by $50 \%$ and the operating expenses by $48.5 \%$ (especially that due to the $42 \%$ increase in staff costs) results in an increase in the value added figure of $70 \%$ (Table 5).

\begin{tabular}{|c|c|c|c|c|c|c|c|c|}
\hline & 2008 & 2009 & 2010 & 2011 & 2012 & 2013 & 2014 & 2015 \\
\hline $\mathrm{Op}$ & $30,468.82$ & $34,819.38$ & $37,523.97$ & $37,383.94$ & $37,899.25$ & $40,969.36$ & $42,966.98$ & $45,449.66$ \\
\hline Staff $c$ & $12,106.24$ & $13,181.31$ & $14,333.03$ & $14,433.44$ & $14,748.70$ & $15,512.17$ & $16,064.15$ & $17,185.71$ \\
\hline Value added & $1,090.80$ & $1,531.23$ & $2,078.83$ & $2,497.69$ & $2,393.92$ & $3,172.15$ & $2,475.92$ & $1,839.06$ \\
\hline
\end{tabular}

Table 5. Analysis of results 


\subsubsection{Analysis of statement of changes in equity}

The equity analysis shows that the net worth increased $60 \%$ in the period analyzed, i.e., the analyzed hospital companies capitalized their assets, especially over the last two years, and offered more guarantees to the third parties involved in them. The capitalization derives from the considerable increase in the net result during the analyzed period $(167 \%)$, which does not differ from the overall result. However, it should be noted that from 2013 on, this result decreases, as does it trend in subsequent years (Table 6).

\begin{tabular}{|l|r|r|r|r|r|r|r|r|}
\cline { 2 - 9 } \multicolumn{1}{c|}{} & \multicolumn{1}{c|}{$\mathbf{2 0 0 8}$} & \multicolumn{1}{c|}{$\mathbf{2 0 0 9}$} & \multicolumn{1}{c|}{$\mathbf{2 0 1 0}$} & \multicolumn{1}{c|}{$\mathbf{2 0 1 1}$} & \multicolumn{1}{c|}{$\mathbf{2 0 1 2}$} & $\mathbf{2 0 1 3}$ & $\mathbf{2 0 1 4}$ & $\mathbf{2 0 1 5}$ \\
\hline Net worth & $12,997.46$ & $15,046.67$ & $17,113.89$ & $18,227.77$ & $19,655.69$ & $19,552.88$ & $20,022.88$ & $20,828.03$ \\
\hline Net income & 376.50 & 823.88 & $1,323.13$ & $1,210.71$ & $1,331.37$ & $1,957.46$ & $1,267.48$ & $1,004.05$ \\
\hline \multicolumn{8}{c}{ Table 6. Equity analysis of Spanish hospital companies }
\end{tabular}

\subsubsection{Treasury analysis (Cash Flow Statement)}

The treasury, i.e., the movement of cash and other equivalent liquid assets, indicates the effect of the collections and payments of these hospital entities in the period considered, according to the operating activity, investment and of financing, and the accounting document that reflects it (the Cash Flow Statement). It presents positive cash flow averages from operating activities (CFOA), since the collections exceed the payments and the hospitals can cope with short-term payments. It presents negative averages for the cash flows from investment activities (CFIA), demonstrating that these centers are investing throughout the period analyzed. The averages of the cash flows of financing activities (CFFA) are positive, since the hospitals request external financing to make their investments, because the hospital activity is immersed (as a result of the technological revolution) in important investments that also help it to overcome the difficult period of the recession. However, in 2013, a large part of this funding is obtained thanks to the important results obtained, so the CFFA is negative. Thus, cash fluctuates during this period and the companies that make up the sample have short-term solvency and make investments with the results obtained and with foreign financing (Table 7).

\begin{tabular}{|l|c|c|r|r|r|r|r|r|}
\cline { 2 - 9 } \multicolumn{1}{c|}{} & \multicolumn{1}{c|}{$\mathbf{2 0 0 8}$} & \multicolumn{1}{c|}{$\mathbf{2 0 0 9}$} & \multicolumn{1}{c|}{$\mathbf{2 0 1 0}$} & \multicolumn{1}{c|}{$\mathbf{2 0 1 1}$} & \multicolumn{1}{c|}{$\mathbf{2 0 1 2}$} & \multicolumn{1}{c|}{$\mathbf{2 0 1 3}$} & \multicolumn{1}{c}{$\mathbf{2 0 1 4}$} & $\mathbf{2 0 1 5}$ \\
\hline CFOA & $2,139.05$ & $3,114.50$ & $3,349.96$ & $1,956.99$ & $2,816.94$ & $4,017.95$ & $3,678.02$ & $4,905.53$ \\
\hline CFIA & $-3,114.07$ & $-3,762.22$ & $-3,436.70$ & $-2,151.43$ & $-2,316.95$ & $-2,150.01$ & $-2,209.90$ & $-2,856.24$ \\
\hline CFFA & $1,776.32$ & 345.41 & 69.93 & -63.58 & 272.96 & $-2,505.49$ & 873.19 & 21.33 \\
\hline
\end{tabular}

Table 7. Analysis of the Cash Flow Statement of Spanish hospital companies

\subsection{Contrast analysis}

To test the hypotheses suggested by the literature review, it must be kept in mind that for statistical Hypotheses 4 and 7 , statistical methods were used for qualitative variables, while statistical methods for quantitative variables, such as Pearson's correlation coefficient, were used for the rest (Bem et al., 2014, 2015).

\subsubsection{Qualitative variables}

To verify whether the presence of CSR indicators and legal form are related to economic profitability, an average difference analysis has been carried out (which compares the averages of the quantitative variable distribution to the two categorical variables). Since these analyses require the quantitative variables to meet the assumptions of normality and homogeneity, the Kolmogorov-Smirnov and the Levene statistical tests have been carried out and it was found that all the variables meet the assumptions of normality ( $\mathrm{p}>0.05)$, so we proceeded to carry out an inferential evaluation, using the Student's t-test for independent samples (Table 8).

In addition, both variables meet the criterion of homogeneity of variances, according to the Levene test $(\mathrm{p}>0.05)$. For these variables, it is assumed that there are equal variations for the determination of the statistical $t$ (Table 9). 


\begin{tabular}{|l|l|r|r|r|}
\cline { 3 - 5 } \multicolumn{2}{c|}{} & \multicolumn{3}{c|}{ KOLMOGOROV-SMIRNOV } \\
\hline \multirow{2}{*}{ RETURN ON ASSETS } & Statistic & \multicolumn{1}{c|}{ n } & \multicolumn{1}{c|}{ p } \\
\hline \multirow{2}{*}{ Legal form } & Public Limited & 0.092 & 50 & 0.200 \\
\cline { 2 - 5 } & Private Limited & 0.110 & 30 & 0.200 \\
\hline CSR indicators & YES & 0.109 & 51 & 0.179 \\
\hline
\end{tabular}

Table 8. Kolmogorov-Smirnov test

\begin{tabular}{|c|c|c|c|c|c|c|c|}
\hline \multirow{2}{*}{\multicolumn{2}{|c|}{ RETURN ON ASSETS }} & \multicolumn{2}{|c|}{ Homogeneity } & \multicolumn{2}{|c|}{ Statistics } & \multicolumn{2}{|c|}{ Student's t } \\
\hline & & Levene & $\mathrm{p}$ & Average & Dev. & $\mathbf{t}$ & $\mathrm{p}$ \\
\hline \multirow{2}{*}{ Legal form } & Public Limited & \multirow{2}{*}{2.082} & \multirow{2}{*}{0.153} & $4.67 \%$ & $8.25 \%$ & \multirow{2}{*}{-0.507} & \multirow{2}{*}{0.614} \\
\hline & Private Limited & & & $5.55 \%$ & $6.32 \%$ & & \\
\hline \multirow{2}{*}{ CSR indicators } & YES & \multirow{2}{*}{0.447} & \multirow{2}{*}{0.506} & $6.71 \%$ & $7.57 \%$ & \multirow{2}{*}{2.793} & \multirow{2}{*}{0.007} \\
\hline & NO & & & $2.00 \%$ & $6.65 \%$ & & \\
\hline
\end{tabular}

Table 9. Inferential statistics for the qualitative variables

Analyzing the results, the testing of the hypotheses using Student's t-test confirms that the presence of CSR indicators on the websites of the sample hospital companies has an influence on the economic profitability, since the average of the return on assets of the hospitals that have CSR indicators are statistically different from those that do not have them, with a level of significance of $5 \%$. In addition, hospitals that have CSR indicators on their websites present a greater percentage of return on assets, since the average obtained is higher $(6.71 \%$ versus $2.00 \%$ ). With regard to legal form of the hospital companies, there is no association with the return on assets (Table 9).

\subsubsection{Quantitative variables}

The main descriptive statistics for each of the quantitative variables of the study (return on assets, short-term solvency, indebtedness, business size, GDP per capita and population density) are reflected in Table 10.

\begin{tabular}{|l|r|r|}
\cline { 2 - 3 } \multicolumn{1}{c|}{} & \multicolumn{2}{c|}{ DESCRIPTIVE STATISTICS } \\
\hline VARIABLES & \multicolumn{1}{c|}{ Average } & Standard deviation \\
\hline Return on assets & $3.43 \%$ & $7.55 \%$ \\
\hline Short-term solvency & 1.52 & 1.30 \\
\hline Indebtedness & 0.61 & 0.28 \\
\hline Business size & 17.37 & 0.87 \\
\hline GDP per capita $(€)$ & $23,778.63$ & $5,193.81$ \\
\hline Population density & $4,591.85$ & $4,182.19$ \\
\hline
\end{tabular}

Table 10. Descriptive statistics for the quantitative variables

Using the Pearson correlation method (which indicates the relationship between variables following a normal distribution), it is checked according to the Kolmogorov-Smirnov test that the variables follow the normal distribution, but the variables of density of population and GDP per capita do not follow it, so they are transformed by applying the Napierian logarithm to ensure a normal distribution (Table 11).

\begin{tabular}{|l|r|r|}
\cline { 2 - 3 } \multicolumn{1}{c|}{} & \multicolumn{2}{c|}{ KOLMOGOROV-SMIRNOV } \\
\hline VARIABLES & Statistic & p \\
\hline Return on assets & 0.074 & 0.200 \\
\hline Short-term solvency & 0.078 & 0.200 \\
\hline Indebtedness & 0.052 & 0.200 \\
\hline Business size & 0.095 & 0.069 \\
\hline GDP per capita (€) & 0.064 & 0.200 \\
\hline Population density & 0.071 & 0.200 \\
\hline
\end{tabular}

Table 11. Kolmogorov-Smirnov test for the quantitative variables 
From here, we analyze the correlation of the return on assets with each of the variables (Table 12).

\begin{tabular}{|l|r|r|}
\cline { 2 - 3 } \multicolumn{1}{c|}{} & \multicolumn{2}{c|}{ RETURN ON ASSETS } \\
\hline VARIABLES & $\begin{array}{c}\text { Pearson correlation } \\
\text { coefficient }\end{array}$ & \multicolumn{1}{c|}{$\mathbf{p}$} \\
\hline Short-term solvency & 0.301 & $\mathbf{0 . 0 0 7}$ \\
\hline Indebtedness & -0.383 & $\mathbf{0 . 0 0 0}$ \\
\hline Business size & -0.201 & 0.073 \\
\hline GDP per capita $(€)$ & 0.279 & $\mathbf{0 . 0 1 2}$ \\
\hline Population density & 0.227 & $\mathbf{0 . 0 4 3}$ \\
\hline
\end{tabular}

Table 12. Correlation between quantitative variables

It is shown that there is a significant relationship between return on assets and short-term solvency, debt, GDP per capita and population density. On the contrary, the business size does not influence economic profitability. The sign of the Pearson correlation coefficient must be taken into account, which indicates that in the case of short-term solvency, GDP per capita and population density, the relationship that occurs with return on assets is positive (better short-term solvency, better GDP per capita and higher population density means higher economic profitability). The relationship between economic profitability and indebtedness is negative, meaning that if the hospitals have little debt, this will improve their economic profitability. We should also point out the strong correlation between short-term solvency and indebtedness with return on assets.

\section{Discussion and conclusions}

This study provides significant evidence regarding the economic and financial analysis for the 2008-2015 period forthe hospital companies that were the subject of study and explains how the economic profitability of these analyzed companies can be improved.

Regarding the financial-economic analysis of the hospital companies for the 2008-2016 period.

- The financial indicators have made it possible to analyze the economic and financial situation of the Spanish hospital companies in line with the literature review (Lee and Choi, 2011), with a balanced distribution of the averages of the financial assets and liabilities in the period considered. They are companies that can handle short-term payments, especially in the latest years analyzed, with working capital and cash flows from operating activities that corroborate this. They can face long-term payments, as they have an acceptable quality of debt, prudent financial management and good management of expenses, but they must improve their asset management. They have had positive financial returns throughout the period, with a tendency for growth until 2013. The return on assets has a more stable behavior in the period analyzed, and the indebtedness does not harm these companies (ROE $>$ ROA). Net profit and net worth increase during the period considered and the hospital companies have recovered and capitalized their assets. They are companies with liquidity that invest in assets combining their own and third-party financing.

In general terms, the economic situation of these hospital companies is optimal, indicating that over time, they optimized their results and achieved a peak in results in 2013. However, we must continue to assess the changes in trends observed.

Regarding the evolution of the dependent variable "return on assets,"as explained by the independent variables in line with the academic literature:

- Return on assets is explained by good short-term solvency and low debt, although it is also affected by the profitability of the assets of hospital companies, and more moderately by GDP per capita, population density and the presence of CSR indicators, in line with the literature review (Bem et al., 2014, 2015; Benton, 2013; Luna et al., 2009). The relationship between the seven independent variables and the dependent variable (ROA) shows a strong positive correlation with short-term solvency, a strong 
negative correlation with debt, a positive correlation with GDP per capita and population density and a positive influence of CSR indicators (Antunes \& Gallardo, 2016). Return on assets is not explained by the legal form of these companies, as opposed to what authors indicated in the literature review (Ayala \& Navarrete, 2004; Turner et al., 2015) (Table 13).

\begin{tabular}{|c|c|c|c|}
\hline & & \multicolumn{2}{|c|}{ VERIFICATION } \\
\hline HYPOTHESIS & VARIABLES & $\sqrt{ }$ & $x$ \\
\hline $\mathrm{H} 1$ & Short-term solvency & $\mathrm{X}$ & \\
\hline $\mathrm{H} 2$ & Indebtedness & $\mathrm{X}$ & \\
\hline H3 & Business size & & $\mathrm{X}$ \\
\hline $\mathrm{H} 4$ & legal form & & $\mathrm{X}$ \\
\hline $\mathrm{H} 5$ & GDP per capita $(€)$ & $\mathrm{X}$ & \\
\hline H6 & Population density & $\mathrm{X}$ & \\
\hline $\mathrm{H} 7$ & CSR indicators & $\mathrm{X}$ & \\
\hline
\end{tabular}

Table 13. Correlation between the qualitative and quantitative variables

Finally, as a limitation of the research, in line with what has been described by Amat (2000), it must be borne in mind that the economic and financial analysis is based on historical data, and there may be a lack of perspective permitting us to know where the hospital companies are headed. We must therefore consider 2016 and subsequent years (once the SABI database collects the opportune financial and economic information) to assess the changes in trends that are taking place in the health field as a result of the technological revolution and the economic policies that they are affected by.

\section{Declaration of Conflicting Interests}

The authors declared no potential conflicts of interest with respect to the research, authorship, and/or publication of this article.

\section{Funding}

The authors received no financial support for the research, authorship, and/or publication of this article.

\section{References}

Amat, O. (2000). Análisis de estados financieros: Fundamentos y aplicaciones (6a ed.). Barcelona: Gestión 2000.

Amat, O., \& Perramon, J. (2011). High-growth cooperatives: Financial profile and key factors for competitiveness. CIREC-España, revista de economía pública, social y cooperativa, 73, 81-98.

Antunes, R.B., \& Gallardo, D.A. (2016). La relación entre la ISO 14001 y el desempeño financiero de las empresas cotizadas en el mercado bursátil en Portugal. In XVII Encuentro AECA. Bragança, Portugal.

Ayala, J.C., \& Navarrete, E. (2004). Efectos tamaño y sector sobre la rentabilidad, endeudamiento y coste de la deuda de las empresas familiares riojanas. Cuadernos de Gestión, 4(1), 35-53.

Barney, J. (1991). Firm Resources and Sustained Competitive Advantage. Journal of Management, 17(1), 99-120. https://doi.org/10.1177/014920639101700108

Bem, A., Predkiewicz, K., Predkiewicz, P., \& Ucieklak-Jez, P. (2014). Determinants of Hospital's Financial Liquidity. Procedia Economics and Finance, 12, 27-36. https://doi.org/10.1016/S2212-5671(14)00317-7

Bem, A., Predkiewicz, P., Ucieklak-Jez, P., \& Siedlecki, R. (2015). Profitability versus debt in hospital industry. In European financial systems 2015. Proceedings of the 12th international scientific conference (20-27).

Benton, W. (2013). A Profitability Evaluation of America's Best Hospitals, 2000-2008. Decision Sciences, 44(6), 1139-1153. https://doi.org/10.1111/deci.12051

Choi, M., \& Lee, K. (2008). A strategy for enhancing financial performance: a study of general acute care hospitals in South Korea. Health Care Manage, 27(4), 288-297. https://doi.org/10.1097/HCM.0b013e31818c806e 
Cleverley, W. (1990). Improving financial performance: a study of 50 hospitals. Hospital \& Health Services Administration, 35(2), 173-187.

Cortés, AM., Rayo, S., \& Lara, J. (2011). Un Modelo Explicativo-Predictivo de la Rentabilidad Financiera de las Empresas en los Principales Sectores Económicos Españoles. En XVI CONGRESO AECA. Granada.

Coyne, J. (1982). Hospital performance in multihospital systems: A comparative study of system and independent hospitals. Health Services Research, 17(4), 303-329.

Creixans-Tenas, J., \& Arimany-Serrat, N. (2016). Gaudeixen de salut financera els hospitals privats catalans?. Intangible Capital, 12(1), 198-222.

Directiva 2013/34/UE del Parlamento Europeo y del Consejo, de 26 de junio de 2013, sobre los estados financieros anuales, los estados financieros consolidados y otros informes afines de ciertos tipos de empresas, por la que se modifica la Directiva 2006/43/CE del Parlamento Europeo y del Consejo y se derogan las Directivas 78/660/CEE y 83/349/CEE del Consejo.

Eldenburg, L., \& Krishnan, R. (2003). Public versus private governance: a study of incentives and operational performance. Journal of Accounting and Economics, 35(3), 377-404. https://doi.org/10.1016/S0165-4101(03)00038-7

French III, H. (1996). Competition and Monopoly in Medical Care. Washington, DC: The AEI Press.

Frías-Aceituno, J.V., Marques, M.C., \& Rodríguez-Ariza, L. (2013). Divulgación de información sostenible: ¿Se adapta a las expectativas de la sociedad?. Revista Española de Contabilidad, RC-SAR., 16(2), 147-158. https://doi.org/10.1016/j.rcsar.2013.07.004

Gapenski, L., Vogel, W., \& Langland-Orban, B. (1993). The determinants of hospital profitability. Journal of Healthcare Management, 38(1), 63-80.

Giner, J., Lorenzo, R.M., \& Abásolo, I. (2005). Análisis financiero de las empresas hospitalarias en Canarias: Un estudio comparado en el conjunto español. In Encuentros ALDE (pp. 1-19).

Global Reporting Initiative (2015). Accessed January 2nd, at: https://www.globalreporting.org/Pages/default.aspx

González-Pascual, J. (2016). Análisis de la empresa a través de su información económico-financiera: Fundamentos teóricos y aplicaciones (5a ed.). Madrid: Ediciones Pirámide.

INE (2015). Instituto Nacional de Estadistica. Accessed December 28th, 2016, at http://www.ine.es/

Instituto para el Desarrollo e Integración de la Sanidad (2017). Sanidad Privada, aportando valor. Análisis de situación 2017. Madrid: IDIS. Accessed at: https://www.fundacionidis.com/wp-content/informes/informe analisis situac idis 2017 web.pdf

Lee, M. (2015). Financial Analysis of National University Hospitals in Korea. Osong Public Health and Research Perspectives, 6(5), 310-317. https://doi.org/10.1016/j.phrp.2015.10.007

Lee, M., \& Choi, M. (2011). Difference of conflict levels of nurses and nurse-aids against doctors. Journal of the Korea Academia-Industrial, 12(11), 4844-4851. https://doi.org/10.5762/KAIS.2011.12.11.4844

Luna, L., Restrepo, J.E., \& Zúñiga, D. (2009). Fluctuaciones macroeconómicas y comportamiento de las empresas en Chile. Economía Chilena, 12(2), 83-95.

Marín-Calahorro, F. (2008). Responsabilidad Social Corporativa y comunicación. Madrid: Fragua.

Mejía, A.F. (2015). La estructura de capital en las medianas empresas del departamento de Boyacá, Colombia. Apuntes del CENES, 34(59), 185-206. https://doi.org/10.19053/22565779.3543

Mick, S., \& Wise, C. (1996). Downsizing and financial performance in rural hospitals. Health Care Management Review, 21(2), 16-25. https://doi.org/10.1097/00004010-199605000-00003

Miras-Rodríguez, M.M., Carrasco, A., \& Escobar, B. (2011). Una revisión de los meta-análisis sobre responsabilidad social corporativa y rendimiento financiero. Revista de Estudios Empresariales. Segunda Época, 1, 118-132. 
Navarro, J.L.\& González, J.M. (2006). Responsabilidad social corporativa y crecimiento económico. Estudios de economía aplicada, 24(2), 723-749.

Nevado-Gil, M.T., \& Gallardo-Vázquez, D. (2016). Información sobre Responsabilidad Social contenida en las páginas webs de los ayuntamientos. Estudio en la región del Alentejo. Revista española de documentación científica, 39(4), e150. https://doi.org/10.3989/redc.2016.4.1353

Ocaña, C., Salas, V., \& Vallés, J. (1994). Un análisis empírico de la financiación de la pequeña y mediana empresa manufacturera española: 1983-1989. Moneda y Crédito, 199, 57-96.

Palomo, RJ., \& Mateu, JL. (1999). Evaluación de la banca cooperativa: Un análisis de las cajas rurales de ámbito provincial mediante técnica de decisión multicriterio. REVESCO. Revista de Estudios Cooperativos, 67, 175-186.

Peteraf, MA. (1993). The cornerstones of competitive advantage: A resource-based view. Strategic Management Journal, 14(3), 179-191. https://doi.org/10.1002/smj.4250140303

Pink, GH., Daniel, I., McGillis, L., \& McKillop, I. (2007). Selection of Key Financial Indicators: A Literature, Panel and Survey Approach. Law \& Governance, 11(3), 87-96. https://doi.org/10.12927/hcq.2007.18661

Prado-Lorenzo, J.M., \& García-Sánchez, I.M. (2010). The role of the Board of Directors in disseminating relevant information on greenhouse gases. Journal of Business Ethics, 97(3), 391-424.

https://doi.org/10.1007/s10551-010-0515-0

Robinson, J., \& Phibbs, C. (1990). An evaluation of Medicaid selective contracting in California. Journal of Health Economics, 8, 437-455. https://doi.org/10.1016/0167-6296(90)90025-X

Rodríguez-Cala, A., Calle-Rodríguez, C., Durán-Garcia, N., \& Zöller, B. (2015). La responsabilidad social corporativa en los hospitales públicos de Cataluña: Un estudio comparativo a través de las páginas web corporativas y la opinión de los responsables de RSC de los centros estudiados. Gest y Eval Cost Sanit, 16(2), 193-205.

Sánchez, J., \& Bernabé, M. (2002). La rentabilidad de la empresa española: Un estudio sobre la década de los noventa. Partida doble, 131, 98-111.

Satorras, M. (2002). La qualitat als centres sanitaris: Experiènces a l'àrea de Barcelona (1a ed.). Barcelona: Edicions UPC.

Scherer, F., \& Ross, D. (1990). Industrial Market Structure and Economic Performance (3rd ed.). Boston, Massachussets, USA: Houghton Mifflin.

Setó, D., \& Angla, J. (2011). La naturaleza de la relación entre la responsabilidad social de la empresa (RSE) y el resultado financiero. Revista Europea de Dirección y Economía de la Empresa, 20(4), 161-176.

Turner, J., Broom, K., Elliott, M., \& Lee, J.F. (2015). A Decomposition of Hospital Profitability: An Application of DuPont Analysis to the US Market. Health Services Research and Managerial Epidemiology, 2, 1-10. https://doi.org/10.1177/2333392815590397

Vélez-González, H., Pradhan, R., \& Weech-Maldonado, R. (2011). The role of non-financial performance measures in predicting hospital financial performance: The case of for-profit system hospitals. Journal of bealth care finance, 38(2), 12-24.

Watkins, A.L. (2000). Hospital financial ratio classification patterns revisited: Upon considering nonfinancial information. Journal of Accounting and Public Policy, 19, 73-95. https://doi.org/10.1016/S0278-4254(99)00025-3

\section{(c) (1) (\$)}

Article's contents are provided on an Attribution-Non Commercial 4.0 Creative commons International License. Readers are allowed to copy, distribute and communicate article's contents, provided the author's and Intangible Capital's names are included. It must not be used for commercial purposes. To see the complete license contents, please visit https://creativecommons.org/licenses/by-nc/4.0/. 